\title{
Diagnostic pitfall; interpretation of CA 19-9 concentrations in the presence of hepatic dysfunction
}

\author{
S Pearce, $H$ Thornes, D Carr, A Tanner
}

\begin{abstract}
A 50 year old man is described with hepatic dysfunction and chronic pancreatitis in whom greatly increased concentrations of the pancreatic tumour marker CA 19-9 combined with an abnormal appearance at endoscopic retrograde cholangiopancreatography lead to the false suspicion of pancreatic carcinoma. CA 19-9 concentrations should be interpreted with caution in patients with intrinsic liver disease or biliary obstruction.

(Gut 1994; 35: 707-708)
\end{abstract}

The non-operative diagnosis of pancreatic malignancy can be difficult and relies upon imaging techniques such as computed tomography or endoscopic retrograde cholangiopancreatography combined with histological examination from aspiration or guided biopsy of a mass.' Recently a monoclonal antibody against CA 19-9, a glycoprotein with structural homology to Lewis blood group antigens has been widely advocated as a specific and sensitive serum tumour marker for pancreatic malignancy. ${ }^{2-5} \mathrm{We}$ report a patient with chronic pancreatitis and transient hepatic dysfunction in whom greatly increased concentrations of CA 19-9 lead to a false suspicion of pancreatic carcinoma.

\section{Case report}

A 50 year old man presented with a $17 \mathrm{~kg}$ weight loss over four months associated with anorexia and an increased frequency of pale stools. Nineteen years previously he had multiple episodes of painful acute, alcoholic pancreatitis. These episodes subsided after he reduced his alcohol -intake but four years later he developed diabetic ketoacidosis and has required insulin treatment to maintain normoglycaemia/euglycaemia since. He smoked 15 cigarettes daily and admitted drinking 10 units of alcohol weekly. $\mathrm{He}$ used $6 \mathrm{U}$ of soluble human insulin before each meal and $10 \mathrm{U}$ of crystalline human insulin zinc suspension at night. He had been prescribed dothiepin $75 \mathrm{mg}$ at night for insomnia four weeks before presentation. He was cachectic but there were no other abnormal physical signs.

The full blood count was normal with a mean red cell volume of $99.5 \mathrm{fl}$. The Westergren erythrocyte sedimentation rate was $48 \mathrm{~mm}$ in the first hour. Serum creatinine, corrected calcium, phosphate, urea and electrolytes, and thyroid stimulating hormone were within the normal range. The patient had acceptable diabetic control, the highest blood glucose over a 24 hour series being $8.3 \mathrm{mmol} / \mathrm{l}$ and the fructosamine $396 \mu \mathrm{mol} / \mathrm{l}$ (normal $<285 \mu \mathrm{mol} / \mathrm{l}$ ). The prothrombin time was 13 seconds (control 12 seconds). His liver function tests were abnormal (Table). Serum vitamin B-12 and red cell folate were normal. A chest radiograph was normal and an abdominal ultrasound scan showed a shrunken pancreas with areas of diffuse calcification but no abnormality of the liver, spleen or biliary tree. A double contrast barium enema examination of the colon was normal. A previously validated test of pancreatic exocrine function showed a slightly subnormal serum concentration of para-aminobenzoic acid at 90 minutes $1.91 \mathrm{mg} / \mathrm{l}$ (normal $>2$ $\mathrm{mg} / \mathrm{l})^{6}$ but this was not felt to explain his recent symptoms. The serum CA 19-9 estimated using a monoclonal antibody enzyme immunoassay (Abbott IMX) was greatly raised at $2690 \mathrm{U} / \mathrm{ml}$ (normal $<25 \mathrm{U} / \mathrm{ml}$ ). The serum carcinoembryonic antigen was $30 \mu \mathrm{g} / \mathrm{l}($ normal $<9 \mu \mathrm{g} / \mathrm{l})$ and the $\alpha$ fetoprotein was 4 IU/l (normal $<10$ IU/ 1). The extremely high concentration of CA 19-9 lead us to suspect that an occult pancreatic carcinoma was the cause of the patient's deterioration. Endoscopic retrograde cholangiopancreatography showed an irregular and dilated pancreatic duct with an abrupt tapering of the main duct in the tail of the pancreas; the biliary tree was normal. These findings gave further weight to the suspicion of pancreatic malignancy and the patient was informed of the probable diagnosis. Computed tomography with intravenous contrast was performed to confirm the presence of a pancreatic mass and define operability. There was no space occupying lesion, however, within the pancreas, only heavy calcification and atrophic pancreatic tissue could be identified. The liver and spleen appeared normal. Liver biopsy was not performed.

The patient was given empirically a course of pancreatic enzyme replacements with meals and kept under observation. His dothiepin was stopped. Over the next four months the patient regained $12 \mathrm{~kg}$ in weight and his stools became normal. The serum CA 19-9 concentration decreased progressively, his liver function became normal (Table) and his mean red cell volume fell to $89 \cdot 1 \mathrm{fl}$. Repeat computed tomography was performed nine months after initial evaluation and showed no change from the original study. The patient remains in good health and has sustained his weight gain over a one year period.

\section{Discussion}

CA 19-9 has been widely advocated as a sensitive and specific marker for pancreatic malignancy..$^{2-5}$ Ritts $e$ al found that a CA 19-9 concentration of 
Serial measurements of CA 19-9 and liver function

\begin{tabular}{llllllc}
\hline $\begin{array}{l}\text { Time } \\
\text { (months })\end{array}$ & $\begin{array}{l}\text { CA 19-9 } \\
(\text { U/ml })\end{array}$ & $\begin{array}{l}\text { Bilirubin } \\
(\mu \text { molll) }\end{array}$ & $\begin{array}{l}\text { Alkaline } \\
\text { phosphatase } \\
(I U / l)\end{array}$ & $\begin{array}{l}\text { AST } \\
(I U / l)\end{array}$ & $\begin{array}{l}\text { Albumin } \\
(\mathrm{g} / \mathrm{l})\end{array}$ & $\begin{array}{l}\text { Mean cell } \\
\text { volume }(f)\end{array}$ \\
\hline 0 & - & 7 & 121 & 56 & 31 & $99 \cdot 5$ \\
2 & 2690 & 28 & 649 & 213 & 30 & $101 \cdot 2$ \\
3 & 741 & 22 & 634 & 126 & 29 & $102 \cdot 8$ \\
4 & 355 & 9 & 355 & 71 & 37 & $98 \cdot 7$ \\
5 & 338 & 6 & 255 & 50 & 40 & $95 \cdot 6$ \\
7 & 218 & 7 & 150 & 35 & 38 & $92 \cdot 6$ \\
9 & 69 & 10 & 100 & 35 & 39 & $89 \cdot 1$ \\
\hline
\end{tabular}

Normal ranges: CA19-9 $<25 \mathrm{U} / \mathrm{ml}$, bilirubin $<17 \mu \mathrm{mol} /$, alkaline phosphatase $20-90 \mathrm{IU} / \mathrm{h}$, aspartate aminotransferase (AST) $<35 \mathrm{IU} / \mathrm{l}$, albumin 40-60 g/l, mean cell volume 78-98 fl.

above $40 \mathrm{U} / \mathrm{ml}$ was present in $81 \%$ of patients with pancreatic cancer and was over $99 \%$ specific for malignancy. ${ }^{2}$ Similar results have been confirmed by other investigators. ${ }^{34}$ In our own population of patients a value for CA 19-9 above $100 \mathrm{U} / \mathrm{ml}$ is $96 \%$ sensitive and $91 \%$ specific for pancreatic carcinoma. ${ }^{5}$

The concentration of CA 19-9 found in serum is a balance between the rate of production of the antigen by both malignant and normal tissues and the rate at which it is cleared from the blood. CA 19-9 is a glycoprotein and in common with carcinoembryonic antigen is probably cleared by hepatic metabolism and excreted in bile. ${ }^{78}$ Basso et $a l^{9}$ have reported CA $19-9$ concentrations in excess of $100 \mathrm{U} / \mathrm{ml}$ in six of 30 patients with benign extrahepatic cholestasis all of which fell towards normal after the obstruction was relieved. This has been confirmed by ourselves and others. ${ }^{45}$ Collazos et $a l^{10}$ found that in a group of 85 patients with cirrhosis seven had CA 19-9 concentrations between 100 and $200 \mathrm{U} / \mathrm{ml}$. Among 74 patients with non-cirrhotic liver disease only one subject with acute hepatitis B had a higher concentration $(425 \mathrm{U} / \mathrm{ml}) .^{10}$

We believe that in our patient transient hepatic dysfunction with predominant cholestasis was the cause of the raised CA 19-9 concentration and his raised carcinoembryonic antigen concentration gives further weight to this hypothesis. The high mean cell volume at presentation together with his previous alcohol abuse point towards alcoholic hepatitis as the probable cause of his hepatic impairment, although it is feasible his recent dothiepin use was responsible for a transient hepatitis. Increase in CA 19-9 concentrations to this degree resulting from intrinsic liver disease has not been reported previously and we advise caution in interpreting serum CA 19-9 concentrations in patients with parenchymal liver disease or biliary obstruction.

We would like to thank Dr R Fifield of the Protein Reference Unit, Cardiff Royal Infirmary for providing the CA 19-9 assay results.

1 DelMaschio A, Vanzulli A, Sironi S, Castrucci M, Mellone R, Staudacher C, et al. Pancreatic cancer versus chronic pancreatitis: diagnosis with CA 19-9 assessment, US, CT and CT-guided fine-needle biopsy. Radiology 1991; 178: 95-9.

2 Ritts RE, DelVillano BC, Go VLW, Herberman RB, Klug TL, Zurawski VR. Initial clinical evaluation of an immunoTL, Zurawski VR. Initial clinical evaluation of an immunoradiometric assay for CA 19-9
Int f Cancer 1984; 33: 339-45.

3 Pleskow DK, Berger HJ, Gyves J, Allen E, McLean A, Podolsky DK. Evaluation of a serological marker, CA 19-9, in the diagnosis of pancreatic cancer. Ann Intern Med 1989; 110: 704-9.

4 Paganuzzi M, Onetto M, Marroni P, Barone D, Conio M, Aste $\mathrm{H}$, et al. CA 19-9 and CA 50 in benign and malignant pancreatic and biliary diseases. Cancer 1988; 61: 2100-8.

5 Welfare M, Tanner A. CA 19-9 estimation in the assessment of pancreatic or biliary tract malignancy - what is the most efficient threshold value? Eur $\mathcal{F}$ Gastroenterol Hepatol 1991; 3: 539-43.

6 Tanner AR, Robinson DP. Pancreatic function testing: serum PABA measurement is a reliable and accurate measurement PABA measurement is a reliable and accurate
of exocrine function. Gut 1988; 29: $1736-40$.

7 McFarlane IG. Hepatic clearance of serum glycoproteins. Clin Sci 1983; 64: 127-35.

8 Thomas P, Zamcheck N. Role of the liver in clearance and excretion of circulating carcinoembryonic antigen. Dig Dis Sci 1983; 28: 216-24.

9 Basso D, Meggiato T, Fabris C, Plebani M, Fogar P, Panozzo MP, et al. Extra-hepatic cholestasis determines a reversible increase of glycoproteic tumour markers in benign and malignant diseases. Eur 7 Clin Invest 1992; 22: 800-4.

10 Collazos J, Genolla J, Ruibal A. CA 19-9 in non-neoplastic liver diseases. A clinical and laboratory study. Clin Chim Acta 1992; 210: 145-51. 